\title{
PRIORITY CARE WITH THE STATUTE OF THE PERSON WITH A DISABILITY AND THE PRINCIPLE OF PRIORITY IN REAL ESTATE REGISTRATION
}

\section{ORIGINAL ARTICLE}

NETO, Alexandre Moura Lima ${ }^{1}$, AGUAIR, Alessandra Anchieta Moreira Lima de ${ }^{2}$, NETO, Haroldo Corrêa Cavalcanti ${ }^{3}$

NETO, Alexandre Moura Lima. AGUAIR, Alessandra Anchieta Moreira Lima de. NETO, Haroldo Corrêa Cavalcanti. Priority care with the statute of the person with a disability and the principle of priority in real estate registration. Revista Científica Multidisciplinar Núcleo do Conhecimento. Year 06, Ed. 09, Vol. 03, pp. 4563. September 2021. ISSN: 2448-0959, Access Link: https://www.nucleodoconhecimento.com.br/law/priority-care, $\quad$ DOI: 10.32749/nucleodoconhecimento.com.br/law/priority-care

\section{ABSTRACT}

The present study aims to analyze the apparent conflict between the priority care of the status of the person with disabilities and the principle of priority of the registration of real estate, that is, if this legal guarantee, gives the person with disabilities priority when noting rights in Notatories. With regard to the methodology used, it is noteworthy that, regarding the purposes of this study, this study is classified as descriptive and explanatory and, as for the means, it is classified as bibliographic, using materials such as books, articles, magazines and reports on the subject. The research is also characterized as a qualitative approach. It was intended to

\footnotetext{
${ }^{1}$ Master in Culture and Society from the Federal University of Maranhão (UFMA). ORCID: https://orcid.org/0000-0002-7232-8449

${ }^{2}$ He holds a Master's Degree in Environment from the Post-Graduate Program in Environment at Universidade Ceuma. ORCID: https://orcid.org/0000-0003-4017-1579

${ }^{3}$ Specialization in Real Estate Law. ORCID: https://orcid.org/0000-0003-1746-1965
}

$\mathrm{RC}: 97614$

Available in: https://www.nucleodoconhecimento.com.br/law/priority-care 
demonstrate that the person with disabilities has the right guaranteed under Law $13.143 / 2015$ to be served quickly, effectively and individually, including in Real Estate Records Registry, but does not enjoy privileges in view of the registral priority in view of the principle of registration priority. From decisions taken by the registered courts of São Paulo, as a result, it is found that the specific provision of Law No. $6,015 / 1973$ prevails in relation to the right of priority care of certain publics, Law $13,143 / 2015$, since it is a material right of priority, and it is understood that granting priority care outside the requirements of art. 186 of Law No. 6,015/1973, is understood to grant priority care outside the requirements of Art. 186 of Law No. $6,015 / 1973$, would represent undeniable affront to legal dictates, which would compromise the service of the right to equality, a premise also of the Statute of persons with disabilities.

Keywords: Statute of the Disabled Person, Registration of Real Estate, Principle of Priority.

\section{INTRODUCTION}

The daily life of people with special needs is complex, considering their limitations and the lack of preparation of society to receive them, both in relation to the infrastructure and mentality of individuals, thus, they end up being socially excluded, activities such as having fun, studying and going to work, which are simple and routine tasks become a challenge to be faced.

As Carlos Henrique Ribeiro da Silva (2008) highlights, the lack of tolerance between the different, throughout history, caused minorities to always be treated relatively aggressively and confusedly, labeling, segregating, discriminating and excluding those who deviated from the standard, which is formed from a hegemonic model. Another very common factor, originated by the lack of understanding about the differences between people is in the person considered different, who assumes very

RC: 97614

Available in: https://www.nucleodoconhecimento.com.br/law/priority-care 
particular attitudes such as self-punishment, isolation and aggressiveness. Thus, it is believed that the lack of tolerance with the different ones has historical roots, although much has already advanced in relation to the subject.

For a long time in Brazil the person with disabilities was considered incapable, with the social changes this fact was being modified and these people began to be recognized as subjects of law and able to make their decisions, so much so that in 2015, Law no. 13,146 changed the Civil Code, instituting the Statute of persons with disabilities. According to Lago (2016), the publication of this Statute aimed at overcoming welfare and overcoming barriers for people with disabilities, as a premise to ensure the right to dignity, civility and full participation in society. However, according to the author, the priority given to these people by the Statute conflicts with the principle of priority in the registration of real estate under Law 6.015/1973 and the Civil Code in order of presentation of the titles, which is the focus of this study. Thus, it will seek to discuss in this essay about the priority in the Statute of persons with disabilities versus the priority described in the Public Records Law (Law 6.015/73). Having as a guide question: whether the person with disabilities, in view of the person with disabilities, enjoys privileges in the face of the other, in the consecration of the registral priority?

The principle of priority, in real estate law, is the fact that it will always have priority to carry out the registration procedures the title presented first before the real estate registry office. According to Art. 186 of the Public Records Act (Law 6.015/73), "the order number will determine the priority of the title, and this is the preference of the royal rights, even if presented by the same person more than one title simultaneously", so that the priority will be determined for the one who first files the title at the real estate registry office. And in the protocol of the notary's office, "all titles will take the number of order that competes with them on the grounds of the rigorous sequence of their presentation" (art. 182).

$\mathrm{RC}: 97614$

Available in: https://www.nucleodoconhecimento.com.br/law/priority-care 
Over the last centuries, the Brazilian registration system has been constantly modified through legislation that aims to monitor the evolution of society as a whole, allowing real estate transactions safety, publicity and effectiveness both for those who participate in it and for those who are interested in it. According to Lima (2011) both notarial and registration activity act as a means of social pacification, ensuring the publicity, authenticity, security and effectiveness of legal acts in a preventive way.

It is important to highlight that although notary and record activities are associated, they should not be confused. Benício (2005) elucidates that this difference can be seen when talking about the function of the registrar and notary (notary), where the former acts with the objective of legitimizing and advertising the acts, while the second encompasses the advice in its functions with subsequent legitimation, authenticity and formalization of legal acts. Still differentiating the two activities, the author states that the notary has as its predominant function the dynamic ${ }^{[4]}$ security, while the registrar the static ${ }^{[5]}$ security, in short, while the notary seeks to safeguard the actum (act), the registrar is limited to publishing the dictum (said).

The activities carried out under notarial law and registration scans should be seen in their social relevance, as Ceneviva (2008) points out, their importance is due to the scope of the acts, which involves from birth to death, recording and giving publicity to all legal acts performed by citizens during their lives, such as marriage, divorce, sharing, inventories, purchase and sale contracts, among others, regularizing all actions performed. Thus, these are activities directly related to the daily lives of individuals.

The social relevance of this study is highlighted, considering that it involves a minority of the population that needs attention in the fulfillment of their rights, and can better clarify about possible conflicts with the principle of priority in the registration of real estate, as well as the professional and academic relevance, since many are still the controversies that revolve around the theme, remaining, with few studies

RC: 97614

Available in: https://www.nucleodoconhecimento.com.br/law/priority-care 
conducted and published on the problem in question, therefore, this research remains justified.

With regard to the methodology used, it is highlighted, based on Maria Cecilia de Souza Minayo (2007), that regarding the purposes of this study classifies as descriptive and explanatory and, as for the means, is classified as bibliographic, using materials accessible to the public such as books, articles, magazines and reports on the subject. The research is also characterized as pure qualitative approach. It was taken as a basis what other authors wrote, being able to understand different points of view on the subject, directing the study in the best way to make the research reliable.

In this context, as previously stated, the present study aims to analyze the conflict between the priority care of the status of people with disabilities and the principle of priority registration of real estate.

\section{PEOPLE WITH DISABILITIES IN A HISTORICAL CONTEXT}

Since the beginning of time there are records of people with special needs. The cultural idea of disability, impotence and dependence of people with motor difficulties cross cultures, societies, sociocultural groups, religions and social practices. The breaking of the expectation of parents with the birth of children affected by some type of motor problem, the acquisition of some sequela from diseases or accidents, are certainly difficult events and have been experienced in many cultures in atypical ways (GUGEL, 2011).

According to Débora Fazolin Koyama (2017) people with physical disabilities have always faced various situations of exclusion and segregation before society, in the period of ancient Greece this was especially portrayed by the city-state of Sparta, since children who were born with some kind of disability were considered as useless to that society and thrown into an abyss.

RC: 97614

Available in: https://www.nucleodoconhecimento.com.br/law/priority-care 
Débora Fazolin Koyama (2017) says that throughout history people with disabilities have always fought a great struggle for life and to conquer their space in society, since the culture imposed by society people has always marginalized them and acted in an exclusionary way with these people.

People with disabilities began to have some of their rights recognized only in the Universal Declaration of Human Rights and from then on, a kick was given to what would become the standardization of fundamental principles to these people, from that moment arose: the principle of the dignity of the human person, principle of equality, among other protective norms. (KOYAMA, 2017)

Ancient Egypt, according to Clemente (2015, p. 34) was known as the "Land of the Blind because its people were constantly affected by eye infections, which resulted in blindness." On the other hand, there are historical records that in places of ancient Greece and Sparta, children with deformities were abandoned in the forests or thrown from gorges.

The Roman laws of antiquity did not protect people with disabilities, on the contrary, legitimized parents to kill their children, through the practice of drowning, abandoned in baskets on the Tiber River, or in other sacred places, some of which were exposed and used as entertainment in circuses. Studies conducted by Lourenzetto (2006) confirm how in the first four centuries of the Christian era, there was no significant expression that favored the insertion of people with disabilities as subjects of dignity and rights.

In antiquity, there are few records of society's relationship with the disabled in everyday life. Through biblical passages, the discrimination that existed at the time against people with disabilities can be perceived, because they are always mentioned as beggars or rejected by the community, that is, they lived on the margins of social and community coexistence. Many believed that these people were punished by the gods (Lourenzetto, 2006, p. 3).

RC: 97614

Available in: https://www.nucleodoconhecimento.com.br/law/priority-care 
In the Middle Ages, disability was considered a metaphysical phenomenon, determined by demonic possession or as god's punishment. Such people were seen as "possessors of an evil due to the pact with the devil", justification used to socially legitimize the extreme use of the campfire as punishment (MAINIERI; ROSA, 2012).

It was believed that such a practice made it possible to humiliate and win against the supposed enemy that had to be defeated. For Maria Aparecida Gugel (2011) besides giving people with disabilities special powers of sorcerers, the children who survived were separated from their families and almost always ridiculed.

Marcella Lourenzetto (2006) makes references on papal documents, that in the case of a person with mental disabilities flee from his reason, he was considered a diabolical being, going on to be persecuted, tortured and exterminated. In the 15th century, such individuals were not yet perceived as human beings.

In these examples, it is explicit how segregation and fatalism affected people with blindness problems and any others who ran away from established standards as normal (BIANCHETTI; FREIRE, 2007). The amputation penalty was also used as control and punishment of traitors in the Roman Constitutions of Emperor Leo III, a process that prevailed in the Roman Empire and the East.

The reasoning introduced nobly in the period of the Inquisition adopted the practice of burning people who brought in their body some difference considered non-normal, or who presented divergent ideas of the status quo or that behaved in a manner considered unsuitable. For this reason, in the inquisition's statements and in the Church's justifications there are no statements that she has burned people. As Lucídio Bianchetti and Ida Maria Freire (2007, p. 33) state, the Church enunciated such an action as [...] "purification by flames". Another explanation of the existence of blind, mute, paralyzed, insane and lepers was that these were conceived as:

$\mathrm{RC}: 97614$

Available in: https://www.nucleodoconhecimento.com.br/law/priority-care 
[...] god's instruments to warn men and women about appropriate behaviors or to provide him with the opportunity to do charity. Thus, the misfortune of some provided means of salvation to others. (BIANCHETTI; FREIRE, 2007, p. 33).

According to Maria Aparecida Gugel (2011), the process of people with disabilities will be recognized as people of dignity and value came with the first hospitals of charity. For the author, between 1214 and 1270, King Luís IX founded the first hospital for blind people victims of the Crusades. The construction of new conceptions about disability was only historically possible in the sixteenth century, when technological and scientific advances enabled the emergence of distinct conceptions in medicine.

It was only in the 16th century, with scientific advances in the field of medicine, that the first dissonated statements about the treatment of the disabled appeared (GUGEL, 2011).

Most men and women were limited to living their day-to-day lives, in a miserable way, involved with production for subsistence. With the gradual predominance of marketfacing production, the possibility of accumulation, the development of a science and new technologies, obtains a relative dominance over nature. With this process, material, social and cultural conditions were created for the construction of emancipatory processes that allow the passage of the sphere of necessity for freedom.

It was not until the 16th century that another historical process different from the previous historical situation was possible. With the advances in medicine that occurred in the 17th century, physical disability was understood as an object of study of medical practice. The process of medicalization of deficiencies implied in the criticism of the historically present visions, that in each man presided over a morbid state, the presence of evil demons influencing health and disease (BIANCHETTI; FREIRE, 2007).

$\mathrm{RC}: 97614$

Available in: https://www.nucleodoconhecimento.com.br/law/priority-care 
The metaphysical explanations of the religious sphere are confronted with the positivist scientific paradigm, so that the theological view on difference loses strength, but influences the theoretical bases for an organicist interpretation. In the 17th century, a great cloister of all those who do not participate in Universal Reason, which was emerging, was unleashed. The one who showed absence of reason in any of its forms, as logical, political, moral reason was cloistered (BIANCHETTI; FREIRE, 2007).

It was only from the mid-19th century that the first institutions for the care of people with physical disabilities began to emerge. For a long time such people were considered only as patients in need of special care and these were seen as people with low potential and with numerous limitations. In Brazil, in the same period, the Imperial Institute of the Blind Boys and the Imperial Institute of the Deaf-Mute were established by order of D. Pedro II, which was established by order of D. Pedro II and the Imperial Institute of the Deaf-Dumb, a fact considered as one of the first Brazilian attitudes for the integration of the disabled in society (SOUSA, 2012).

However, the creation of cloistering devices also generated processes of segregation of the social environment, resulting in this, the construction of what Erving Goffman (2008, p.13) defines as stigma, "[...] a special type of relationship between attribute and stereotype", being understood in the context of human relations and not substantive. "An attribute that stigmatizes someone can confirm the normality of others."

The issue of disability takes another focus due to the observation of the paradigm shift, nodded in the 1970s, of the last century, integrative actions are advocated in order to favor the presence/insertion of people with disabilities in the same social spheres as the others. However, this possibility appears as something utopian in its real functionality, because as Erving Goffman explains (2008, p. 134):

RC: 97614

Available in: https://www.nucleodoconhecimento.com.br/law/priority-care 
The special situation of the stigmatized is that society tells him that he is a member of the broader group, which means that he is a normal human being, but also that he is to some extent , "different", and that it would be absurd to deny this difference. The difference itself derives from society, because in general, before a difference is important it must be collectively conceptualized by society as a whole.

Thus, the insertion of this public in the different social spheres is increasing every year, although physical facilities, the supply of material and the training of professionals to care for people with special needs are still precarious, focusing this study on the rights of these citizens, more specifically integration, inclusion and equality, based on the basic principle of the dignity of the human person.

\section{HUMAN RIGHTS WITH AN EMPHASIS ON PEOPLE WITH DISABILITIES}

Human rights with an emphasis on people with disabilities, in addition to the dignity of the human person and equality, need to highlight the right to mobility and the city, as well as education and health, given that they are crucial factors in order to ensure the social inclusion of these people. Throughout the evolutionary process of human civilization there was the search for rights ranging from locomotion to circulation in public and private environments independently.

Historically, people have been disrespected and totally excluded from social life, especially from the social context and this was based on the ideas they had about the human being and the society that was inculcated in individuals forming a mental model that settles in this and no longer disappears. It just transforms (LOPES et al., 2009, p. 29).

The perspective of citizens' rights historically achieved has brought the idea of integration, inclusion, equality as a way of coping with the processes of social exclusion, discrimination and stigmatization. This process is fundamental, like sidewalks that guarantee the right to come and go of any citizen in the city where he lives.

$\mathrm{RC}: 97614$

Available in: https://www.nucleodoconhecimento.com.br/law/priority-care 
In Brazil, this process involved the recognition of the right to accessibility. In the Federal Constitution, Chapter VII, Art. 227 provides for the "facilitation of access to collective goods and services, with the elimination of architectural prejudices and obstacles", thus having rules that guarantee the construction of adaptation of places, public buildings and public transport. (NOGUEIRA, 2010, p. 51). In 1981, for example, the United Nations - UN recognized in a convention the international year of people with disabilities. In 1989, these rights were amended by Law No. 7,853, whose purpose is to establish "the judicial protection of collective or diffuse interests of these persons, disciplines the performance of the Public Prosecutor's Office, defines crimes, and provides other measures" (BRASIL, 1989). The same law determines compliance with the enforcement of the rules by municipalities in order to promote the functionality of buildings and public roads for the disabled.

Finally, Federal Law No. 10,098 of December 19, 2000[6], subsequently regulated by Decree No. 5,296 of December 2, 2004[7], standardizing the issue of accessibility as an adaptation goal and access institution. To date, however, this law has not been implemented, since items such as access to public buildings, permanence and use available in these buildings, such as education and health were not fully contemplated. Sidewalks are the portrait of exclusionary society, making it necessary to solve emergency issues, such as holes in the streets, cars on sidewalks interrupting mobility, standardization of ramps, handrails, walkways, public toilets and special signage so that accessibility problems can be minimized (COELHO, 2010).

In this sense, the right to accessibility is an indispensable factor not only for those who have some kind of disability or reduced mobility, but for society as a whole, because based on the principle of equality everyone is equal before the law and enjoy the same rights to come and go, education, leisure, housing, tourism and culture. According to the Declaration of the Rights of Persons With Disabilities, adopted at a General Assembly of the United Nations (UN) in 1975, it proclaims

RC: 97614

Available in: https://www.nucleodoconhecimento.com.br/law/priority-care 
among other resolutions that: "Disabled people are entitled to measures aimed at empowering them to become as self-confident as possible."

The World Charter of the Right to the City approved at the Social Forum of the Americas in Quito, the World Urban Forum in Barcelona in 2004 and the Fifth World Social Forum of Porto Alegre in 2005 establishes commitments between governments and organized civil society to promote cities based on the principles of solidarity, freedom, equality, social justice and dignity.

The right to the city is defined in the Charter as: "The equitable enjoyment of cities within the principles of sustainability, democracy and social justice [...] is interdependent on all internationally recognized rights". The city is in this document conceived as "culturally rich and diversified collective space that belongs to all citizens" (CARTA MUNDIAL DO DIREITO À CIDADE, 2004, p. 2). As for the special protection of vulnerable groups and persons, the City Charter states:

Cities through policies of positive affirmation to vulnerable groups must overcome political, economic and social obstacles that limit the freedom, equity and equality of citizens, and that prevent the full development of the human person and effective participation in the political, economic, cultural and social organization of the city (CARTA MUNDIAL DO DIREITO À CIDADE, 2004, p. 3).

With regard to urban mobility, article 13 states:

1. Cities guarantee the right to mobility and movement in the city through a system and public transport accessible to all people according to a plan of urban and long-distance travel and, based on the appropriate means of transport the different social needs (gender, age, disability) and environmental, with prices appropriate to citizens' incomes. The use of non-contaminating vehicles will be encouraged and pedestrian areas will be permanently reserving at certain times of the day.

RC: 97614

Available in: https://www.nucleodoconhecimento.com.br/law/priority-care 
2. The cities will promote the removal of architectural barriers for the implementation of the necessary equipment for the mobility and circulation system and the adaptation of all public or public buildings, workplaces, to ensure the accessibility of people with special needs (CARTA MUNDIAL DO DIREITO À CIDADE, 2004, p. 3).

It is worth mentioning that when it comes to accessibility it is not limited to the physical space where it is installed, it is the city as a whole that represents the political, social, economic and intellectual process of society.

In the field of education and health, it is emphasized that school inclusion is configured as a right of the citizen guaranteeing universally, highlighting as a milestone of this process the Salamanca Declaration, which emphasizes inclusive education, following the conventions and human rights, aimed at children and adolescents, presenting here, the main ones, as merit of basic knowledge of the subject.The document was named after a World Conference on Special Education in Salamanca in 1994, which aimed to restructure policy reform according to inclusion, stating that:

Every child has a fundamental right to education, and should be given the opportunity to achieve and maintain the appropriate level of learning, every child has characteristics, interests, skills and learning needs that are unique, educational systems should be designated and educational programs should be implemented in order to take into account the wide diversity of such characteristics and needs, those with special educational needs should have access to the regular school, which should be able to support them within a childcentered Pedagogy, capable of meeting such needs, regular schools that have such inclusive guidance are the most effective means of combating discriminatory attitudes by creating welcoming communities, building an inclusive society and achieving education for all; in addition, such schools provide effective education to most children and improve efficiency and ultimately the cost of the effectiveness of the entire educational system (...)" Thus cites the document (UN, 2010, p. 78).

RC: 97614

Available in: https://www.nucleodoconhecimento.com.br/law/priority-care 
This proclamation places us in the obligation to offer and provide opportunities for children and adolescents specific programs and tailored evaluation, ensuring the full development and development of the potential of each individual. For this, the readaptations of the Curriculum should be considered and be contemplating the guarantee of law.

This is an international agreement on the rights of children and adolescents. Whereas, in accordance with the principles proclaimed in the Charter of the United Nations, the recognition of the inherent dignity and equal and inalienable rights of all members of the human family is the foundation of freedom, justice and peace in the world and bearing in mind that the peoples of the United Nations reaffirmed in their Charter their confidence in the fundamental human rights and dignity and value of the human person and have determined to promote social progress and better living standards in greater freedom.

The National Policy of Special Education (PNEE) in the Perspective of Inclusive Education (PEI) (2008) highlights the need to confront the segregation of students in the school environment and proposes a special education that develops in a complementary way, reaffirming the unique education system.

In this context, human rights are universal and no citizen can be excluded for any reason because of their physical, mental conditions, or by color, race, custom or social class, therefore, it is up to the authorities to develop public policies to care for these individuals equally.

Thus, recognizing that people with disabilities have priorities, among them, of preferential, fast and individualized care, they realize the enjoyment of fundamental rights stamped in the Federal Constitution of 1988. However, it should be clarified that, because it is a very personal right, this right should be exercised for the benefit of the person with disabilities, or by persons who are in the condition of vulnerability, under federal law 10.048, of November 8, 2000[8], which consecrated the priority of

RC: 97614

Available in: https://www.nucleodoconhecimento.com.br/law/priority-care 
care to the persons it specifies: people with disabilities, pregnant women, lactating women, people accompanied by children on their lives, in addition to the elderly.

It is also evidenced that the personal condition of the party is not the main highlight of the Statute of the Person with Disabilities, what is sought is the preferential, immediate and individualized care of the vulnerable part, in our study, the person with disabilities in Notaries.

\section{STATUS OF PERSONS WITH DISABILITIES AND THE PRINCIPLE OF PRIORITY OF PROPERTY REGISTRATION}

In the context of notary and registration services, in addition to compliance with the basic principles of public administration, it is necessary that notawills and registrars also meet principles considered as specific to these activities. It is important to understand that the principles are malleable, given that they adapt to the historical and social circumstances they go through.

The principles applied to the registration services involve the actions to be carried out throughout the registration process, from registration to rogation, being related to Real Estate Law. The principle of registration, according to Carvalho (2011), is the beginning of the process, being responsible for the constitution, transmission, modification or extinction of the rights in ris. It is, therefore, the record of acts that alter or extinguish any act of registration.

The principle of advertising already mentioned as the basic principle of public administration is still considered, and registrars should make public the records made within their Notariotories. According to Ceneviva (2008), advertising as a principle of registration activity aims to fulfill its threefold function, which is to transmit the registration to the knowledge of third parties, to inform about assets and rights of individuals who receive benefits arising from the act of registration, sacrificing, even

RC: 97614

Available in: https://www.nucleodoconhecimento.com.br/law/priority-care 
partially, their right to privacy and intimacy and promoting acts for statistical purposes, national interest or public oversight.

The principle of the presumption of truth applied to the registered services is also a result of the public faith granted to them together with the delegation of the function. Vasconcelos and Cruz (2000) elucidate that public faith must extend to all acts performed within the scope of registration services, responding positively to the existence of real rights. Thus, it is always assumed that everything that is inscribed in the real estate registry is true until proven otherwise.

In turn, the principle of priority deals with the question of the order of inscriptions in the registration of real estate, and the registrar should consider the chronological order of presentation of the titles, according to art. 186 of Law No. 6,015/1973. Antunes (2005) points out that it is the chronological order that should determine the priority of the title and the preference of the real right.

The principle of specialty or determination of records brings that the registration must be made so that the description of the property is accurate and with its peculiar characteristics, such as registration, order number, date, identification of the property, confrontations, location and area. In addition, it is also necessary to include data of its owner such as name, domicile, nationality, marital status, profession, general registry number $(R G)$ and, in case of legal entity, must be included in the social company and the number of the National Registry of Legal Entities (CNPJ). The correct description of these data is essential to provide legal certainty to the acts performed (ANTUNES, 2005).

Continuing the description of the principles of the registered services has the principle of qualification, legality or legitimacy that, according to Antunes (2005), the registrar must examine the title presented considering the form, validity and compliance with the law. Galiani (1995) also mentions that even to examine the title given to him, the registrar must avail himself of the legislation, not being able to go

$\mathrm{RC}: 97614$

Available in: https://www.nucleodoconhecimento.com.br/law/priority-care 
beyond the limits established by law, and should analyze only the formal aspects of it.

The principle of continuity is also part of the list of principles applied to registration services, being highlighted by Antunes (2005) as one of the foundations of these services. On the application of this principle, Balbino Filho (2001) elucidates that it brings the obligation of continuity of registration, maintaining the connection between the different businesses that came to modify the legal-real situation. Thus, all changes that occur in the title must be recorded in the same document, preserving the previous information.

Finally, there is the principle of the instance or rogation, which deals with the action taken by the registrar based on the request of the parties. According to Balbino Filho (2001), the principle of instance or rogation concerns the solicitation of any registral act, and must be simple, independent in a special way, and may be express or tacit. Expressed when it is clearly expressed by the parties and tacit when the registrar can identify the will of the parties recounting their experience.

In view of the above, the registration services must be performed in compliance with the principles mentioned, and it cannot be forgotten that the basic principles of public administration should be considered in all activities performed by registrars within the scope of their functions.

Discussions about the principle of priority of real estate registration have been a matter of discussion, so much so that it is possible to identify cases judged that consider conflicts with rights of certain publics. Lago (2016) cites the granting of priority in the care of lawyers and the granting of priority care to the elderly, both of the Court of Records of São Paulo - SP. In the first was denied due to the specific legal provision regarding law 8.906/1994 - Statute of the Brazilian Bar Association, and the violation of the order of precedence, however, a recommendation was made

$\mathrm{RC}: 97614$

Available in: https://www.nucleodoconhecimento.com.br/law/priority-care 
to grant priority care in cases where notaries and registered judges, under prudent criteria, necessary.

In the second case, the magistrates used the criteria defined by Law 6.015/1973 and the Civil Code, stating that the order presented should be strictly followed. With this, it was left the understanding that priority care would be granted to the elderly in the provision of certificates or in the delivery of documents, but not in the entry of titles that could generate priority (LAGO, 2016).

From this, it is possible to take this understanding also in the case of people with disabilities, since its Statute also provides for the right to priority care. It was found that in the view of the registered courts, the specific provision of Law No. 6,015/1973 prevails in relation to the right of priority care of certain audiences, since it deals with a material right of priority, being understood that granting priority care outside the requirements of Art. 186 of Law No. 6,015/1973, would represent undeniable recognition of extralegal cause, which would compromise the service to the right to equality, a premise also of the Statute of the Person with Disabilities.

The principle of priority is laid down in the arts. 182 and following, of Law No. $6,015 / 73$. It is mentioned, for example, its incidence on the mortgage and acts surrounding it, although redundant, is also contained in the Civil Code, in art. 1493, in verbis: "The records and endorsements shall follow the order in which they are requested, verifying that of their successive numbering in the protocol." Thus, there is no as request of a disabled person your request fulfilled before those who succeeded him in a Registry Office. In this sense Afrânio Carvalho (2011):

(...) in a contest of real rights over a property, they do not all occupy the same rank, but graduate or qualify by a relationship of precedence based on the chronological order of its appearance: prior tempore potior jure. Depending on the time in which they arise, the rights take a position in the register, prevailing those previously established over those that come after. (CARVALHO, 2011, p. 216).

RC: 97614

Available in: https://www.nucleodoconhecimento.com.br/law/priority-care 
It is elucidated that the titles that generate priority right must enter the Real Estate Registry, upon release in Book No. 1 - Protocol, according to the strict order of presentation described in the Public Records Law. For this reason, any right to preferential care due to disability, age, gender do not allow, in terms of these titles, to be received before others who have already entered the premises of the service in the first place. Applying the principle of registration priority, a title should be registered, in the first place, according to the lowest protocol number, "depressing the registration of those presented later, for the period corresponding to at least one working day" (Law 6.015/73, art. 191). However, although the principle of priority to the disabled is not applied, in both cases the titles should be registered.

In order to solve the problem, Lago (2016, p. 316) suggests "a system of a system composed of a password-provider device with certain characteristics, and two simultaneous protocol books - one preliminary and one definitive". However, it is believed that the problem goes beyond, not being sufficient for solution, considering the autonomy of the registral system and the intention of promulgating the Statute of the Person with Disabilities, it is understood that priority care in this case should not occur, otherwise it would harm the right to equality.

\section{CONCLUSION}

The notary and registration services were addressed in this study considering them in their activity carried out by the private sphere by delegation of the Public Power, taking into account being focused on the social interest, therefore, due to obedience to the general principles of public administration, in addition to principles specific to these activities that must be observed in each act.

In addition to the obedience to specific principles of these activities, which are that of the inscription, the publicity, the presumption of truth, the priority, that of the specialty or determination of the records, that of qualification, legality or legitimacy, that of

RC: 97614

Available in: https://www.nucleodoconhecimento.com.br/law/priority-care 
continuity and instance or rogation, as well as of public faith, which one of the main mentioned in the case law.

The subject was addressed from the perspective that, although the rights of people with disabilities are guaranteed in the Federal Constitution, the reality reveals a great distance between formal rights and their effectiveness, verifying that there were numerous public policies aimed at people with disabilities throughout history in search of accessibility, mobility and equality of rights, integrating them into society, however, it is evident that there is still a significant path to be followed for their rights to be effectively effected.

Within the registration system, it was found that there is a conflict between its provisions of the principle of registration priority and the Statute of the Person with Disabilities that provides for priority care to this public. It turns out that in this system material rights are focused, therefore, considering the Statute of the Person with Disabilities for priority care would have consequences such as the possibility of circumventing or defrauding the legal system in force in the country.

Thus, from similar decisions taken by the registers of São Paulo, it was perceived that the specific provision of Law No. 6,015/1973 prevails in relation to the right of priority care of certain publics, since it deals with a material right of priority, being understood that granting priority care outside the requirements of art. 186 of Law No. $6,015 / 1973$, would represent undeniable recognition of an affront to the real rights of citizens, which would compromise the service to the right to equality, a premise also of the Statute of persons with disabilities.

Finally, as a way of answering the question that is the guide of this essay, it is accepted that the guarantee of the mechanism of registration priority does not contrast with the generally established faculty in the Statute of persons with disabilities. The rules of this are not imposed on the rules of Law 6.015/1973. They deal with such diplomas in different situations. In other words, it is worth the

$\mathrm{RC}: 97614$

Available in: https://www.nucleodoconhecimento.com.br/law/priority-care 
protective rule up to the limit that it is not excluded by another, of public order, which desecrates, to the interested parties, the registral priority and at the remote end the preference and definition of the real rights.

\section{REFERENCES}

ANTUNES, Luciana Rodrigues. Introdução ao Direito Notarial e Registral. Jus Navigandi, Teresina, ano 9, n. 691, 2005.

BIANCHETTI, Lucídio; FREIRE, Ida Mara (orgs.). Um olhar sobre a diferença: interação, trabalho e cidadania. 6. ed. São Paulo: Papirus. 2007.

BRASIL. Constituição da República Federativa do Brasil, de 05 de outubro de 1988. Brasília, 1988. Diário Oficial da União. Disponível em: http://www.planalto.gov.br/ccivil_03/Constituicao/Constituicao.htm Acesso em: julho.2021.

BRASIL. Decreto № 5.296 de 2 de dezembro de 2004. Diário Oficial da União, 3 dez. 2004. Disponível em: http://www.planalto.gov.br/ccivil_03/_ato20042006/2004/decreto/d5296.htm . Acesso em: 25 jul. 2021.

BRASIL. Lei n. 13.105, de 16 de março de 2015. Disponível em: $<$ https://www.planalto.gov.br/ccivil_03/_ato2015-2018/2015/lei//13105.htm> Acesso em: jul.2021.

BRASIL. Lei o 10.406, de 10 de janeiro de 2002. Institui o Código Civil. Diário Oficial da União: seção 1, Brasília, DF, ano 139, n. 8, p. 1-74, 11 jan. 2002.

BRASIL. Lei ㄲo. 10.048, de 08 de Novembro de 2000. Diário Oficial [da República Federativa do Brasil], Brasília. Disponível em: https://www.presidencia.gov.br/ccivil_03/Leis/L10048.htm . Acesso em: 30jul.2021.

RC: 97614

Available in: https://www.nucleodoconhecimento.com.br/law/priority-care 
BRASIL. Lei ㄲo. 10.098, de 19 de Dezembro de 2000. Diário Oficial [da República Federativa do Brasil], Brasília. Disponível em: https://www.presidencia.gov.br/ccivil_03/Leis/L10098.htm . Acesso em: 30jul.2021.

BRASIL. Presidência da República. Lei 7.853 de 24 de outubro de 1989. Disponível em:http://www.planalto.gov.br/ccivil_03/leis/l7853.htm - Acesso em 26/07/2021.

CARTA Mundial do Direito à Cidade. Fórum Social das Américas - Quito - Julho 2004; Fórum Mundial Urbano - Barcelona - Setembro 2004; V Fórum Social Mundial - Porto Alegre - Janeiro 2005. Disponível em: Acesso em: 30 jul. 2021.

CARVALHO, Afrânio de. Registro de imóveis. Rio de Janeiro: Editora Forense, 2011.

CENEVIVA, Walter. Lei dos notários e registradores comentada. São Paulo: Saraiva, 2008.

CLEMENTE, Carlos Aparício. Lei de cotas para o trabalho de pessoas com deficiência: Análise e fundamentação dos principais argumentos favoráveis e contrários ao seu cumprimento. 2015.

GALIANI, Luiz Antônio. Os princípios basilares do fólio real. RJ n. 212, jun/95.

GOFFMAN, Erving. Estigma: notas sobre a manipulação da identidade deteriorada. 4‥ ed. Rio de Janeiro:LTC, 2008.

GUGEL, Maria Aparecida. Benefício da prestação continuada e trabalho: Mudanças da Lei $\mathrm{N}^{\circ}$ 12.470, de 31 de agosto de 2011. Disponível em: Acesso em jul.2021.

RC: 97614

Available in: https://www.nucleodoconhecimento.com.br/law/priority-care 
KOYAMA, D. B. Os reflexos da lei 13.146/2015 - Estatuto da Pessoa com Deficiência - no sistema jurídico brasileiro. Universidade Presbiteriana Mackenzie, São Paulo, 2017.

LAGO, Ivan Jacopetti do. O atendimento prioritário da Lei Federal 13.146/2015 (Estatuto da Pessoa Com Deficiência) e o princípio da prioridade do registro de imóveis.Revista de Direito Imobiliário,São Paulo, ano 39, v.80, jan-jun.2016.

LORENTEZ, Lutiana Nacur. A norma da igualdade e o trabalho das pessoas portadoras de deficiência. São Paulo: LTr, 2006.

MAINIERI, Tiago; ROSA, Elisa Costa Ferreira. Comunicação pública, cidadania e democracia-algumas reflexões. Revista Comunicação Midiática, v. 7, n. 1, p. p. 192-206, 2012.

ORGANIZAÇÃO DAS NAÇÕES UNIDAS (ONU). Declaração de Direitos do Deficiente Mental - 1971. Aprovada pela resolução n. A/8429 da Assembleia Geral da ONU de 22 de dezembro de 1971. Disponível em: http://www.direitoshumanos.usp.br/index.php/Direito-dos-Portadores-deDefici\%C3\%AAncia/declaracao-de-direitos-do-deficiente-mental.html. Acesso em $27 / 07 / 2021$

SILVA, C. H. R. Teoria das Incapacidades. [online]. 2008. Disponível em: <http://www.ribeirodasilva.pro.br/teoriadasincapacidades.html> Acesso em: jul.2021.

VASCONCELOS, Julenildo Nunes; CRUZ, Antônio Augusto Rodrigues. Direito notarial: teoria e prática. [S.I.] Juarez de Oliveira, 2000.

\section{APPENDIX - REFERENCE FOOTNOTE}

4. Set of legal measures to protect situations in the process of being set up, modified or extinguished.

$\mathrm{RC}: 97614$

Available in: https://www.nucleodoconhecimento.com.br/law/priority-care 
5. Set of legal measures proposed to keep established situations

6. It establishes general standards and basic criteria for promoting accessibility for people with disabilities or reduced mobility, and provides other measures.

7. It regulates the Laws in 10,048 , of November 8,2000 , which gives priority to care to people it specifies, and 10,098, of December 19, 2000, which establishes general standards and basic criteria for the promotion of accessibility for people with disabilities or reduced mobility, and provides other measures.

8. It gives priority to care to the people it specifies, and provides other measures.

Submitted: July, 2021.

Approved: September, 2021.

RC: 97614

Available in: https://www.nucleodoconhecimento.com.br/law/priority-care 